\title{
Otobiografia como escuta das vivências presentes nos escritos*
}

Silas Borges Monteiro

Universidade Federal de Mato Grosso
Correspondência:

Silas Borges Monteiro

Univ. Federal de Mato Grosso

Av. Fernando Correa da Costa, s/n

e-mail: silasmonteiro@ufmt.br

\section{Resumo}

Este texto é parte da fundamentação teórica da tese de doutorado intitulada: Quando a Pedagogia forma professores: uma investigação otobiográfica, defendida na Faculdade de Educação da Universidade de São Paulo. 0 objetivo deste texto é explicitar o sentido de otobiografia, abordagem teórica que fundamentou o método da pesquisa. Esse conceito metodológico, construído a partir de Jacques Derrida, busca mostrar o sentido das vivências resultante da escuta que Nietzsche sugere ser feita. Essas vivências operam na produção escrita. Por isso, com a otobiografia, questiona-se a dynamis do texto, designando-a como a força, a potência virtual e móbil que dão vivência aos escritos. Pela investigação otobiográfica, importa dar outro sentido ao biográfico e sua assinatura - o autobiográfico. Derrida nos ajuda a pensar a estreita vinculação entre as vivências e a produção textual, amparado pela leitura que faz de Nietzsche. Entende que só artificialmente podemos separar um texto da vida de seu autor. Com esse método, é possível - e esse foi o objetivo da tese de doutorado - escutar as vivências de professores em formação por meio dos seus escritos. 0 pesquisador, nesse caso, coloca-se como ouvinte das vivências de formação, afinal são elas que nos mostram os valores e os saberes efetivados ao longo de um tempo de vida. 0 texto está estruturado da seguinte forma: depois de constituída questão que sustenta este trabalho, o conceito otobiografia é estabelecido a partir do livro homônimo de Derrida e dos textos de Nietzsche. Procuro mostrar o que está em foco na investigação otobiográfica, qual seja: a audição das vivências. Para tal, é forçoso restabelecer a questão geradora da pesquisa: o que quer o autor ao escrever seu texto? A trilha labiríntica sulcada por esse método persegue as vivências presentes nos escritos.

\section{Palavras-chave}

Otobiografia - Filosofia - Nietzsche - Formação de professores.

"Este texto foi apresentado no II CIPA (Congresso Internacional de Pesquisa Autobiográfica), Salvador - BA, em setembro de 2006. 


\section{Otobiography as listening to the experiences present in the writings*}

Silas Borges Monteiro

Universidade Federal de Mato Grosso
Contact:

Silas Borges Monteiro

Univ. Federal de Mato Grosso

Av. Fernando Correa da Costa, s/n

e-mail: silasmonteiro@ufmt.br

"This text was presented to the $2^{\text {nd }}$ CIPA (International Congress of Autobiographical Research) in Salvador - BA in September 2006.

\begin{abstract}
This text is part of the theoretical foundation of my doctoral thesis entitled When Pedagogy forms teachers: an otobiographical investigation, presented to the Faculty of Education of the University of São Paulo. The purpose of the present article is to explain the meaning of otobiography, the theoretical approach that gave support to the research method. This methodological concept, based on the work of Jacques Derrida, seeks to reveal the meaning of experiences, which results from the kind of listening suggested by Nietzsche. These experiences take place in the written production. Thus, the otobiography questions the dynamis of the text, designating it as the force and the virtual and mobile power that give life to the writings. Through the otobiographical investigation one is concerned to give new meaning to the biographical and its signature - the autobiographical. Derrida helps us here to think the close ties between the experiences and the textual production, supported by the reading he makes of Nietzsche. He understands that only artificially it is possible to separate a text from its author's life. With this method it is possible - and this was the objective of our doctoral work - to listen to the experiences of teachers in formation through their texts. The researcher here puts himself as listener of the experiences of formation; after all, they are what reveal to us the values and knowledges developed in a lifetime. The text is structured in the following way: after establishing the question that drives this work, the concept of otobiography is explained based on the book by the same name by Derrida and on Nietzsche's texts. We try to show what is under focus in an otobiographical study, namely, listening to experiences. For that, one must resume the research's founding question: what does the author want when he/she writes his/her text? The labyrinthine path rutted by this method pursues the experiences present in the writings.
\end{abstract}

\section{Keywords}

Otobiography - Philosophy - Nietzsche - Teacher education. 


\section{Constituição da questão que sustenta este trabalho}

Este texto parte de um conceito usado por Derrida (1984), otobiografia, para construir elementos de reflexão e análise acerca do sentido de um escrito. É pressuposto que a produção escrita contribui para a construção do sentido de vida do escritor. A autoria descreve seu autor. Com Derrida, nesse caso apresentado como leitor de Nietzsche, é mostrado que os sentidos das vivências dos autores dinamizam os escritos. Com isso, o filósofo francês questiona a dynamis do texto, designando-a como a força, a potência virtual e móbil que dá ao texto vivência. Derrida, auscultador de Nietzsche, ajuda-nos a pensar a vinculação entre a vivência e a produção textual e também a filosófica. Para ele, só artificialmente podemos separar um texto da vida de seu autor. 0 escrito é a verdade do autor e, portanto, de seu texto. Não perquire pelo fundamento último da exposição, mas pelo sentido interno dado ao dito. A investigação otobiográfica se propõe a ouvir a vida implicada na formação, à medida que a produção escrita é formativa. A metáfora despertada pela escuta concilia-se com a de labirinto: o ouvido, em sua anatomia, aproxima-se da forma labiríntica; a mitologia convida Ariadne para a escuta desenovelada. Investigar otobiograficamente é procurar pelas vivências da formação presentes nos escritos. São essas vivências que nos mostram os valores e os saberes efetivados ao longo do processo de vida, por que não vitae: currículo.

\section{Otobiografia: o livro de Derrida}

Ao que me consta, otobiografia foi um conceito criado por Jacques Derrida, publicado em livro homônimo. Esse é o texto integral de uma conferência pronunciada na Universidade de Virgínia (Charlottesville), em 1976, Estados Unidos. Na França, é publicado em 1984. 0 pretexto $^{1}$ da elaboração é a comemoração da independência do Estados Unidos, e divide-se em quatro partes: 1. Declaração de indepen- dência; 2. Lógica da vivência; 3. Do estado o signo autógrafo; 4. Omphalos.

Na primeira parte do livro, Derrida (1984) procura mostrar que todo "ato declarativo funda uma instituição” (p. 16), ainda mais que as declarações são assinadas, o que lhes dá conotação de um signatário, ou seja, alguém que, por representar um grupo, se afirma por ele: "A declaração que funda uma instituição, uma constituição ou um estado, requisita que um signatário esteja aí engajado" (p. 16-17), de modo que, o nome da declaração fala "em nome do povo" (p. 21). Derrida faz a mesma crítica de Nietzsche: esse povo não existe, assim como afirma Zaratustra: "Em algum lugar há ainda povos e rebanhos, mas não entre nós, meus irmãos: aqui há Estados"; esse que afirma a mentira que "sai rastejando da sua boca: 'Eu, o Estado, sou o povo!' Onde ainda existe um povo, este não compreende o Estado e o odeia como má sorte e uma ofensa aos costumes e ao direito". Como nasce "gente demais", para os "supérfluos inventou-se o Estado!" Aqueles que se curvam a esse "monstro frio", lhes são peculiar "as orelhas compridas e vista curta". Estado é o lugar onde "o lento suicídio de todos chama-se - "vida'!" E finaliza:

Onde cessa o Estado, somente ali começa o homem que não é supérfluo, ali começa o canto do necessário, essa melodia única e insubstituível. Onde o Estado cessa olhai para ali, meus irmãos! Não vedes o arco-íris e as pontes do além-do-homem? (Nietzsche, 2000, p. 75-77)

De carona no alter ego de Nietzsche, Derrida examina o sentido do Estado como recolhedor das vontades de todos. Afirma que, mesmo sob a máscara do Estado, há assinaturas que por ele firmam intenções, que fundam instituições.

Na segunda parte, Derrida (1984) mostra a lógica da vivência dizendo:

1. 0 uso que faço desse termo encontra-se no sentido que Deleuze e Guatarr dão ao plano imanente na elaboração dos conceitos, qual seja, o que serve de fundo para a construção dos conceitos, algo próximo de um motif. Por ser pré-texto, serve como antecedente do tecido que recolhe a produção. 
Um discurso sobre vida-e-morte deve ocupar um certo espaço entre o logos e o grama, a analogia e o programa, os diferentes sensos do programa e da reprodução. E já que se trata da vida, o traço que relaciona lógica ao gráfico deve funcionar entre o biológico e o biográfico, o thanatológico e o thanatográfico. (p. 39)

Nesse entre dois, encontra-se a elaboração crítica da filosofia. Por isso, a biografia, quando é tratada na Filosofia, vai além dos acidentes empíricos dos autores. Entretanto, também vai além dos exames estruturalista dos textos. Opta por questionar a dynamis do texto, designando-a como a força, a potência virtual e móbil que dão ao texto vivência.

Isso que se chama vida - coisa ou objeto da biologia e da biografia - não faz face, essa é a primeira complicação, a qualquer coisa que será por ele um objeto oponível: a morte, a thanatológica ou a thanatográfica. A 'vida' tem também o mal de tornar-se objeto de uma ciência no sentido que a filosofia e a ciência dão hoje à palavra, como ao estatuto legal da cientificidade. (Derrida, 1984, p. 41)

Afirma que as ciências são, por seu tipo, ligadas à morte, pois criam objetos recortados de sua dinâmica, de sua vida. A fisiologia é um exemplo, pois estuda corpos mortos e retalhados. Derrida insiste na co-implicação entre o biográfico e biológico para ressignificar as ciências "da morte". Buscar pelas assinaturas é parte integrante dessa revitalização do objeto morto a um sentido de vivência. No entanto, importa dar outro sentido ao biográfico e sua assinatura: o autobiográfico. Não merecem essa inscrição as descrições de eventos importantes ou significativos dos vivos para que lhes imortalize. 0 que está em tela não são os acidentes empíricos que marcam o trajeto do nascimento à morte. Para Derrida (1984), autobiográfico, ao menos em Nietzsche, relaciona a descrição para si mesmo:
Esse relato que enterra a morte e salva o salvo como imortal, ele não é autobiográfico porque o signatário conta sua vida, o retorno de sua vida que passa como vida e não como morte; mas porque essa vida ele a conta para si, ele é o primeiro senão o único destinatário da narração. (p. 41)

Tecnicamente, a filosofia tem chamado isso de reflexão, pois é retorno do pensamento sobre si mesmo, destinando-se sua descrição, análise e avaliação.

$\mathrm{Na}$ terceira parte do livro, Derrida trata do Estado e de seu signo autobiográfico, ou seja, suas instituições. Estas assinam pelo Estado, Ihes dão dinâmica. São elas que o Estado procura, a todo o momento, salvar. São elas que lhe dão identidade. E no caso da apresentação do filósofo francês, as instituições que ele trará em questão são as de ensino, sustentado em Nietzsche com seu texto de 1872: Sobre o futuro de nossas instituições de ensino. No Ecce Homo, é afirmado pelo filósofo alemão: "Algum dia necessitarão de instituições em que se viva e se ensine como eu entendo viver e ensinar; talvez sejam instituídas cátedras próprias para a interpretação de Zaratustra" (Nietzsche, 1995, p. 52). Por isso, Zaratustra é um mestre, "ele dispensa uma doutrina e intenta ser fundador de novas instituições" (Derrida, 1984, p. 74). Essas novas instituições de ensino, Nietzsche já as tratou bem antes do seu Zaratustra. Tanto naquele texto como neste, para ele, o problema é a falta de ouvidos para seu ensinamento ${ }^{2}$. Melhor ainda: denuncia a falta de ouvidos para as vivências, afinal, "para aquilo a que não se tem acesso por vivência, não se tem ouvido" (\$1). Por essa que Derrida (1984) afirmará: "Com o ensinamento e com suas novas instituições, ele trata também do ouvido. Tudo se enrola, vocês sabem, no ouvido de Nietzsche, nos motivos de seu labirinto" (p. 76). 0 código do labirinto é duplo, remete a um dobrado: é uma das

2. Nietzsche (1995) admite sua precocidade: "que hoje não se ouça, que hoje não se saiba tirar nada de mim, não é somente compreensível, parece-me até mesmo justo" (Nietzsche, Assim falava Zaratustra, Por que escrevo livros tão bons, §1). 
partes do ouvido, ou seja, é fisiológico3 ${ }^{3}$ é caminho de Ariadne, tema de Nietzsche ${ }^{4}$. Ariadne também é a que aprendeu a ouvir e que, depois de se ligar a Dioniso, teve suas orelhas encurtadas.

Derrida desenvolve a idéia do livro de Nietzsche de 1872 com dois protocolos. 0 primeiro, afirmando a peculiaridade do texto que, a pedido de Nietzsche, deveria ser publicado apenas postumamente, pois o considerava inacabado: pretendia escrever seis conferências, mas redigiu apenas cinco. 0 segundo protocolo postula que são conferências inscritas no âmbito universitário: foram escritas para acadêmicos pelo professor Nietzsche em Basiléia; as conferências que postulam o futuro das instituições de ensino são dirigidas a universitários por um acadêmico. A crítica de Nietzsche recai sobre a reestruturação da instituição de ensino alemã que deposita sobre o professor o papel destacado na formação, restando aos estudantes seguirem esse ou aquele, amparados pela liberdade acadêmica. "No entanto, toda a desgraça dos estudantes de hoje em dia explicase pelo fato de que eles não têm achado um Führer" (Derrida, 1984, p. 91). Derrida mostra que por trás da "liberdade acadêmica se desenha a silhueta de um constrangimento tanto mais feroz e implacável que ele se dissimula e se disfarça em lasser-faire. Através da dita 'liberdade acadêmica', o estado, por ela, controla tudo" (p. 103-104). Derrida mostra que o Estado impõe obrigações rígidas demais para sustentar a idéia de uma liberdade acadêmica. Na pseudo-sensação de autonomia, os professores obedecem às normas acadêmicas oriundas do Estado, e não da própria instituição. Por isso, Derrida sugere que leiamos

\section{[...] estas conferências como uma crítica moderna aos aparatos culturais do Estado que constituía, ontem mesmo, a sociedade industrial, o aparato escolar. (p. 104)}

No texto, escrito como uma espécie de narrativa autobiográfica, Nietzsche apresenta um professor já afastado da universidade com quem conversa, ainda jovem estudante, sobre o que tem vivido no ambiente acadêmico. Lá pelas tantas, o sábio professor se dirige ao jovem estudante Nietzsche e seu colega, com as seguintes palavras:

Quando um estrangeiro vem conhecer o sistema das nossas universidades, ele pergunta com insistência: "De que modo o estudante está ligado à universidade?" Nós respondemos: "Pelo ouvido, como ouvinte". 0 estrangeiro se espanta: "Somente através dos ouvidos?", pergunta ele. - "Somente através dos ouvidos", respondemos novamente. 0 estudante escuta. Quando fala, quando vê, quando anda, quando está acompanhado, quando tem uma atividade artística, em suma, quando vive, ele é autônomo, quer dizer, independente do estabelecimento de ensino. Com bastante freqüência, o estudante escreve enquanto ouve. Estes são os momentos em que está preso pelo cordão umbilical à universidade. Ele pode escolher o que quer ouvir, não precisa acreditar naquilo que ouve, pode tapar os ouvidos quando não queira ouvir. Eis o método acroamático de ensino. (Nietzsche, 2003, p. 125)

0 que permite a liberdade de escolher o que ouvir é o fato de já estar atado pelo ouvido. Unido a esse cordão umbilical, a liberdade acadêmica é realizada. Sua natureza é acroamática, isto é, agradável aos ouvidos.

$\mathrm{Na}$ parte final do livro, Omphalos (umbigo em grego), Derrida explora uma das teses principais do texto: a identificação da morte ao

3. Na introdução de seu livro Margens da filosofia, Derrida desenvolve a análise da "troca metafísica, a cumplicidade das metáforas do olho e do ouvido" (p.13). Ele quer pôr o "ser no limite". Timpanizar o ser é fazê-lo ecoar sob diversos martelos, mesmo que com isso seja luxado o ouvido filosófico; afinal a filosofia pode existir sem margens.

4. Deleuze explora as imagens de Ariadne e do labirinto em um ensaio intitulado "Mistério de Ariadne", publicado em Magazine Litteraire, n. 298 em 1992. Assim ele termina o texto: "0 labirinto já não é o caminho onde nos perdemos, mas o caminho que retorna. Já não é o labirinto do conhecimento e da moral, mas o labirinto da vida e do Ser como vida. Quanto ao resultado da união de Dioniso e Ariadne, esse resultado é o além-do-homem, o super-herói, o contrário do homem superior. 0 além-do-homem é aquele que vive nas cavernas e nos cumes, a única criança feita pelas orelhas, o filho de Ariadne e do Touro". Adiante no texto, serão feitas observações complementares a esse tema. 
discurso do pai e a vida à figura da mãe, mais precisamente, à da mulher: a língua materna. Aproxima-se de uma interpretação psicanalítica de Nietzsche.

A grande contradição é que as instituições de ensino prendem seus estudantes pelo ouvido. Os alunos ouvem o tempo todo. Contudo, não aprendem a ouvir o que deve ser escutado: as vivências.

\section{Otobiografia: o conceito}

Derrida nos ajuda a pensar a vinculação entre vivência e produção filosófica. Mais ainda, a propósito de sua exposição sobre estilo filosófico de Nietzsche, procura demonstrar seu ensino compreendido a partir do Zaratustra, como vinculação de seu nome, o nome próprio, como uma assinatura de sua filosofia. Como poucos, Nietzsche pensa a filosofia fundada em sua própria experiência - o que pode não mostrar alguma originalidade -, mas a assume como sua filosofia, gestada em suas vivências. Ouvir as vivências de seu autor: eis o grande desafio à filosofia. "O ouvido, então, também está no marco de seu ensino e em sua nova instituição" (Derrida, 1984, p. 75-76).

A tese central de Derrida é que só artificialmente podemos separar um texto da vida de seu autor, o que não significa se prender ao psicologismo peculiar da produção filosófica no início do século XX. Deve-se reconhecer que foi o estruturalismo que permitiu profissionalizar a produção filosófica na França e por aqui também. Esse método tem por princípio não separar as teses dos movimentos lógicos que as produziram, e refazer o itinerário intelectual do autor por procedimento genético. 0 que é sustentado aqui vincula os movimentos às lógicas que produzem, bem como a busca da gênese do pensamento dos autores. Com tais procedimentos, buscou-se superar o psicologismo que dava tom à produção filosófica, como se essa fosse uma espécie de terapia do filósofo, procurando cruzar as afirmações feitas com as experiências psicológicas de seus autores. No estruturalismo, o principal material de trabalho é o texto. 0 labor sobre ele caracteriza a produção filosófica.

0 princípio do trabalho no texto não é sem propósito. Como nos lembra Deleuze (1974),

[...] é com razão que se apresenta a lingüística como origem do estruturalismo: não somente Saussure, mas também a Escola de Moscou, a Escola de Praga. [...] só há estrutura daquilo que é linguagem, nem que seja uma linguagem esotérica ou mesmo não verbal. Só há estrutura do inconsciente à medida que o inconsciente fala e é linguagem. Só há estrutura dos corpos à medida que se julga que os corpos falam com uma linguagem que é a dos sintomas. As próprias coisas só têm estrutura à medida que mantêm um discurso silencioso, que é uma linguagem dos signos. (p. 272)

0 triunfo do manejo da palavra, que caracteriza o trabalho filosófico do século $X X$, busca mais do que verdades: pesquisa pela estrutura que sustenta e dá significado ao discurso. Essa é a verdade do autor e de seu texto. Não perquire pelo fundamento último da exposição, mas pelo sentido dado ao dito. Na Filosofia, portanto, o que vale é o corpo-a-corpo com o texto, num trabalho paciente e de anos, que leva ao conhecimento do autor.

Derrida, quando inscreve Nietzsche na otobiografia, aplica o método estrutural, apesar de ser também seu crítico. Quer encontrar os sintomas - aliás, este é um conceito-chave em Nietzsche expressos nos textos e coloca-se como ouvinte atento destes. Busca no autor de Zaratustra as chaves de leitura de seus escritos. Sabe que "ninguém pode ouvir nas coisas, inclusive nos livros, mais do que já sabe. Para aquilo a que não se tem acesso por vivência, não se tem ouvido" (Nietzsche, 1995, p. 53). Por isso, pensa sobre uma nova instituição em que se aprenda a ouvir. Não poupa veneno para as instituições que, mesmo prendendo pelo ouvido, não ensinam a escutar. Alia-se à crítica de Nietzsche, quando esse afirma: 
Todas as questões da política, da ordem social, da educação foram falsificadas pela base e pelo fundamento por tomarem os homens mais perniciosos por grandes homens - por aprenderem a desprezar as 'pequenas' coisas, quer dizer, as disposições fundamentais da própria vida. (Nietzsche, 1995, p. 50)

0 cerne do problema é o desprezo pelas disposições fundamentais da própria vida, desprezo compreendido por que não aprenderam a ouvir as vivências. Ouvir é marco conceitual, é leitmotiv de seu labirinto. 0 par conceitual ouvido-labirinto é fecundo em Nietzsche e aqui neste trabalho também. Estando as vivências no âmago da argumentação com a proposta de ouvi-las, não cabem trilhas sem rodeios ou circunlóquios, pois a dinâmica não se expressa por traçados lineares, sem relevos: não há aterrados. Esse trajeto é sinuoso, ondulante, diria tortuoso, porém audível, assim como o labirinto membranoso permite a audição humana.

0 filósofo francês põe em cena a radical relação que tem a filosofia com a linguagem e a incompetência auditiva de apreendê-la em sua estrutura. Se ambos ateiam fogo destruidor nas instituições e seus ensinos, fazem-no sob o lema de fênix que, ao ser incinerada, revive das cinzas. Com a crítica do martelo, destrói para reconstruir. Se denuncia o ensino por seu método acroamático, percebe Nietzsche pegar, também, a ciência pelo pé, como anota em um de seus fragmentos: "Acroamático. Portanto, ciência!" (Nietzsche, 1977, p. 342)

A referência do labirinto deve ser entrecruzada com um ditirambo escrito por Nietzsche sobre Ariadne - a personagem que vence o labirinto por amor a Teseu: "por que tuas orelhas não são ainda mais longas?" (Nietzsche, 2006, p. 74). 0 método de ensino acroamático cumpre o papel de dilatar orelhas, pois seduz pelo prazer de ouvir sem exigir o empenho da resposta, do diálogo. São ouvintes passivos. Não é esse ouvinte que Nietzsche qualifica como bom para ouvir as vivências.

\section{O que está em questão na investigação otobiográfica}

Escrito em 1872 com o intuito de ser proferido como conferências na universidade em Basiléia, Nietzsche vale-se do estilo narrativo, criando a figura de um filósofo, conhecido por sua sabedoria, e seu assistente, que encontram um grupo de jovens, entre eles Nietzsche, e entabulam uma conversa sobre os apetites experimentados nos estudos: é uma espécie de avaliação dos programas escolares e do sentido que as escolas dão à formação intelectual de uma geração. 0 ponto central da discussão é a insistência do filósofo sobre a importância da língua para a cultura. Nietzsche é um jovem, nesse diálogo - que se apresenta autobiográfico - e, ao mesmo tempo, empresta suas idéias ao filósofo, crítico da cultura e da formação alemã daqueles dias. Depois de mostrar o abuso que estão fazendo com a língua, banalizando-a, o filósofo afirma o vínculo umbilical da universidade com seus estudantes pelo ouvido, como já mostrei: “'De que modo o estudante está ligado à Universidade?' Nós respondemos: 'Pelo ouvido, como ouvinte'” (Nietzsche, 2003, p. 125). A ironia das metáforas de Nietzsche revela sua visão sobre a pobreza da formação acadêmica, pois não oferecia espaços para que algo mais do que o ouvido pudesse ser exercitado, algo mais pudesse ser dito, além das lições dos professores. Não era a vida que estava em foco nessa instituição. Até mesmo no conteúdo ministrado, havia desqualificação. Nietzsche acentua sua crítica vendo a decadência da formação cultural de seu país.

No entanto, para essa tarefa, usa metáforas como o ouvir, visto, nesse caso, como o extremo da passividade de um estudante, cuja preocupação é meramente reprodutora, na verdade, transcritora. 0 ouvido, como órgão, está em seu uso inadequado: funciona como mera captação acústica, porta de entrada semi-escancarada, sem intencionalidade ou, por vezes, interesse. 0 tédio é o que determina o que se 
põe para dentro. 0 professor, do outro lado, produz a acústica que pretende ser sorvida. Para tanto, gosta de ter grande audiência. Inflama-lhe o ego ser conhecido como culto, sábio, instruído, bem formado. Adora ouvir a própria voz.

Entretanto, entre eles, a distância é abissal.

Derrida (1984) se permite ler esse trecho psicanaliticamente. Ele transfere às metáforas as figuras do pai (o mestre), da mãe (a língua) e do cordão umbilical que liga ambos ao estudante, mostrando a reprodução de um sistema que procura manter a não-autonomia, privando a criação e valorizando a sujeição. Fará uma nota que pode lançar elementos novos nessa interpretação:

0 ouvido é misterioso. Misterioso é o que é; o dobro é o que se pode tornar; grande ou pequeno é o que ele pode fazer ou deixar acontecer (como em laisser-faire, visto que o ouvido é o mais evidente e o órgão mais aberto, aquele que, como Freud nos lembra, a criança não pode fechar); grande ou pequena como tal, assim é a maneira pela qual se pode oferecer ou emprestar o ouvido. (p. 106)

0 ouvido é duplo; seu próprio duplo. Pode estar passivo - ligado umbilicalmente a algo que o sustenta, que o mantém - ou pode estar preparado para receber novos, confusos, irritantes, constrangedores, libertadores ou tantos outros sons. Para esses tantos, Nietzsche se diz preparado. Novamente, "uma coisa sou eu, outra são meus escritos. - Aqui, antes que eu fale deles próprios, seja tocada a pergunta pelo entendimento ou não-entendimento desses escritos". 0 duplo também aparece: ele e seus escritos. Em Nietzsche, são muitas as falas que tomam a palavra. E isso se vê claramente nas diversas assinaturas que percorrem sua obra: "0 crucificado", "Dioniso" e outros. Simplificaria muito imaginar que uma força patológica estaria em questão. Perderíamos a riqueza de sua contribuição se ficássemos com essa interpretação - risco que pode acometer aquele que lê o poeta português Fernando Pessoa e seus heterônimos: Alberto Caeiro, Álvaro de Campos, Ricardo Reis, Bernardo Soares e, porque não, Fernando Pessoa. 0 ponto é entender que ouvir implica também as vivências, que suscitam as mais diversas experiências, inclusive as denominadas cognitivas. Na mesma sessão de Ecce Homo, Nietzsche dirá: "ter entendido seis frases do meu Zaratustra, isto é: tê-las vivido, eleva, entre os mortais, a um grau superior ao que homens 'modernos' poderiam alcançar", querendo com isso reafirmar a importância das vivências para o entendimento das coisas. Com Nietzsche, julgo que a compreensão é da radical ordem da vivência, para qual temos de ter ouvidos: em uma palavra, interpretação. Escutar a biografia - otobiografia - ainda pode captar melhor o que quer essa vida ouvida.

\section{A questão de fundo da investigação otobiográfica}

Uma pesquisa é mobilizada por questões. É de Deleuze que virá a formulação metódica da investigação que estou denominando de otobiográfica. Em seu livro Nietzsche e a filosofia, Deleuze (s/d) argumenta que o autor de Zaratustra empenha-se em criticar a predominância de conceitos passivos, ou como resume: "por todo lado, nas ciências do homem e mesmo da natureza, aparece a ignorância das origens e da genealogia das forças” (p. 113). Logo, investigar as produções humanas - mais do que nas ciências humanas - significa instalar o sentido vetorial das forças que mobilizam o conhecimento ou as forças das vivências que produzem o texto. A interrogação que põe em movimento a reflexão nietzschiana é: "o que quer?" De outro modo: o que querem as forças das vivências ao produzir um texto, um escrito, um conceito, uma idéia, uma teoria, uma interpretação etc.? Aplicada à filologia, Deleuze (s/ d) enuncia: "uma palavra só quer dizer qualquer coisa à medida que aquele que diz quer qualquer coisa ao dizê-lo. E só uma regra: tratar a fala como uma atividade real, colocar-se no ponto de vista daquele que fala” (p. 113). Com isso, há significativa mudança na fórmula da interrogação 
filosófica. A tradição ocidental estabelece como questão de fundo a fórmula "o que é?" Deleuze sugere outra: "quem?” Usa como antecedente: "0 quê? perguntava-me com curiosidade. - Quem? deverias tu interrogar-te! Assim fala Dioniso". (Nietzsche, 1982, p. 211) Assim a explica:

\section{'Quem?', segundo Nietzsche, significa o seguinte: sendo uma coisa dada, quais são as forças que dela se apoderam, qual é a vontade que a possui? Quem é que se ex- prime, se manifesta, e mesmo se esconde nela? Somos conduzidos à essência apenas pela questão: Quem? Porque a essência é apenas o sentido e $o$ valor da coisa; a essên- cia é determinada pelas forças com afinidade com a coisa e pela vontade com afinidade com essas forças. Mais ainda: quando colo- camos a questão: '0 que é?' caímos apenas na pior metafísica, de fato, não fazemos mais do que pôr a questão: Quem? mas de uma maneira indireta, cega, inconsciente e confusa. (Deleuze, s/d, p. 116-117)}

No projeto nietzschiano, interpretado por Deleuze, sempre cairemos no questionamento acerca das forças vitais que impulsionam a produção humana: calibrar essa questão significa ir ao âmago do que é interrogado. Sua fórmula mais precisa é "quem?"

0 momento propositivo da pesquisa otobiográfica é o questionamento de quem toma a palavra na produção, por exemplo, de um escrito. Qual é a vida, a vontade, as vivências que são postas em movimento? Quem fala? 0 que se quer, quando algo é dito?

Interrogar ao que fala, ou ao que escreve, põe em ação, talvez, uma espécie de método clínico, que pode ser efetivado sob três formas:

Uma sintomatologia, à medida que interpreta os fenômenos, tratando-os como sintomas, cujo sentido é necessário ser procurado nas forças que os produzem. Uma tipologia, à medida que interpreta as próprias forças do ponto de vista da sua qualidade, ativa ou reativa. Uma genealogia, à medida que avalia a origem das forças do ponto de vista da sua nobreza ou da sua baixeza, à medida que encontra a sua ascendência na vontade de potência e na qualidade desta vontade. As diferentes ciências, mesmo as ciências da natureza, têm a sua unidade numa tal concepção. Mais do que isso, a filosofia e a ciência possuem a sua unidade. Quando a ciência deixa de utilizar conceitos passivos, deixa de ser um positivismo, mas a filosofia deixa de ser uma utopia, uma quimera sobre a atividade que compensa este positivismo. 0 filósofo enquanto tal é sintomatologista, tipologista, genealogista. Reconhece-se a trindade nietzschiana, do 'Filósofo do futuro': filósofo médico (é o médico que interpreta os sintomas), filósofo artista (é o artista que modela os tipos), filósofo legislador (é o legislador que determina a ordem, a genealogia). (p. 114-115) ${ }^{5}$

Talvez, no limite, o que se produz da otobiografia é uma filosofia ou ao menos um exercício de filosofia de estirpe nietzschiana. Talvez. Aqui a tomo como ferramenta de trabalho de escuta dos escritos.

\section{Otofisiologia: labirinto}

Quero retomar uma afirmação feita por Derrida (1984): "Como vocês sabem, todas as coisas chegam a termo no ouvido em Nietzsche, nos refrãos de seu labirinto" (p. 98). Como sabemos, o ouvido é formado de três partes: ouvido externo, médio e interno. Externo refere-se ao que vemos: a orelha, em forma de pavilhão, que capta as ondas sonoras e as transportam pelo meato acústico externo até a membrana do tímpano, ou seja, está em ação a recepção e o transporte acústico. 0 tímpano (um dos elementos do ouvido médio) transfere as ondas, pela cavidade timpânica, ao ouvido inter-

5. Estas figuras do filósofo (médico, artista, legislador), Nietzsche as constrói ao longo de suas obras. 
no, onde encontrará o labirinto membranoso que possui receptores nervosos, ligados ao cérebro, para a interpretação das ondas sonoras.

Essa otofisiologia é metafórica: Derrida brinca com os termos. Quando fala do ouvido de Nietzsche, recreia-se em lembrar do labirinto que, nesse caso, possui duas conotações: um orgânulo do ouvido e um termo caro ao poeta de Ariadne, oriundo da mitologia grega. Como sabemos, a idéia de labirinto está relacionada ao mito do Minotauro. A figura de destaque do mito é Ariadne, filha de Minos, rei de Creta. Teseu veio à Creta como uma das quatorze vítimas que os atenienses anualmente eram obrigados a oferecer ao Minotauro, um monstro metade touro, metade homem, que vivia confinado no labirinto construído pelo arquiteto Dédalo. Quando Ariadne viu Teseu, apaixonouse pelo rapaz. Ofereceu-se a ajudá-lo a sair do labirinto caso ele vencesse a besta-fera. Pela ajuda, Ariadne pede em troca que o jovem a leve para Atenas. Ela então lhe deu um novelo de linha que havia conseguido com Dédalo. Amarrando uma das extremidades do novelo na entrada do labirinto e outra em seu corpo, após matar o Minotauro, ele seria capaz de escapar do labirinto enrolando o novelo novamente. Com o sucesso do plano, Teseu e companheiros fugiram pelos mares em direção à Atenas, levando Ariadne com eles. No meio do caminho, pararam na ilha de Naxos. De acordo com a lenda, Teseu abandonou Ariadne na ilha, enquanto ela dormia. Conta outra versão que ela foi resgatada por Dioniso, com quem, a contragosto, casou-se. Atinemos: Dioniso é herói de Nietzsche.

A figura do Fio de Ariadne tornou-se, para o ocidente, a metáfora da solução para problemas difíceis de resolver. Descartes (1984) a usa em suas Objeções e respostas. Está em questão o rigor do uso de procedimentos para sair de problemas emaranhados ou de difícil solução. É a aposta moderna de que procedimentos rigorosos solucionam impasses. Se por um lado temos Ariadne como a solução de enigmas, por outro, temos Dédalo como criador deles. É curioso notar como Nietzsche trata essas personagens mitológicas.
Inicialmente, ignora Dédalo, mas não faz o mesmo com Ariadne, dando-lhe, ao longo de sua obra, conotações levemente diferentes. Nos escritos da fase helenística, o autor de $O$ nascimento da tragédia a vê do modo como foi vista na modernidade: aquela capaz de trazer luz para a saída do túnel, aquela que dissipa a névoa, aquela que é capaz de esclarecer as mentes a respeito dos problemas impostos pelo conhecimento. Em Além de bem e mal, Ariadne é apresentada como noiva de Dioniso - assumindo uma das versões do mito - vivendo na ilha de Naxos - lugar onde foi abandonada por Teseu e resgatada pelo deus. Embora, assim, ainda carregue conotação semelhante à da fase helenista, visto que Dioniso ama em Ariadne aquilo que ama nos mortais: "animal agradável, valente, inventivo, que não tem igual sobre a Terra, em todo labirinto ele é capaz de se achar" (Nietzsche, 1996, p.197). Já em Crepúsculo dos ídolos, de $1888^{6}$, nas Incursões de um extemporâneo, ao tratar do "Belo e feio", lemos um Nietzsche com suas reflexões antimetafísicas destinadas ao belo: denuncia o absurdo do "beloem-si", evidencia o juízo "belo" como "vaidade genérica” e sentencia: "nada, absolutamente nada nos garante que justamente o homem forneça o modelo da beleza". Cria, então, para seu filósofo estimado, Dioniso, o seguinte diálogo com a bela e sábia princesa Ariadne:

'Oh Dioniso, divino, por que tu me puxas as orelhas?', perguntou Ariadne certa vez a seu amante filosófico, em um daqueles célebres diálogos por sobre a ilha de Naxos. 'Eu vejo algo de gracioso em tuas orelhas, Ariadne: por que elas não são ainda mais longas?' (Nietzsche, 2006, p. 74)

Ao longo da sua produção, Nietzsche foi encurtando as orelhas de Ariadne. Por fim, elas não são mais longas.

De modo mais diverso desse anterior, nos poemas da coletânea Ditirambos de Dioniso, o

6. Marton (1993) distingue três períodos nos textos de Nietzsche: 1870-1876, denominado de "pessimismo romântico"; 1876-1882, denominado de "positivismo cético"; 1882-1888, denominado de "transvaloração dos valores". 
divino fala à sua amada mortal: "tens orelhas pequenas, tens as minhas orelhas" (Nietzsche, 2000a, p. 71). A ambigüidade auditiva por que passa Ariadne fascina o deus. Todavia, não seria essa dubiedade a melhor condição do caminhar no labirinto? Não seriam os ambíguos aqueles preparados para as trilhas tortuosas? Talvez, por essas razões, Nietzsche julgaria mal-feita a leitura que dá ao mito conotação apenas de resolução de problemas. Acentua a ambigüidade presente na condição humana, mostrando que é justamente esse humano, demasiado humano que encontra suas trilhas no labirinto, afinal, "quem além de mim sabe o que é Ariadne?” (Nietzsche, 1995, p. 93)

Por coerência, quando trato do método otobiográfico, pelas sugestões ilustradas na fisiologia e na mitologia, o labirinto é uma figura que pode colaborar para a sua compreensão, lembrando que a palavra método é usada nesse momento com a conotação de caminho, a partir da etimologia na língua grega. Estou ciente que mesmo a palavra caminho, por vezes, leva-nos a pensar em uma estrada, trilha, o que pressupõe estar percorrendo um rastro anterior, já realizado, montado, feito, pronto, já efetuado, eficiente: reta; com sentido e destino conhecido previamente; funciona por causa e efeito: se vou por aqui, chego acolá; levará, certamente a lugar conhecido. Parece-me raro pensar em labirinto como caminho, pois está fortemente fincada à idéia de que ele é feito para perder-se.

Ao mesmo tempo, pensar num método cuja metáfora é o labirinto, dificilmente poderia proceder por raciocínio hipotético-dedutivo ou empírico-indutivo. Não é possível tal conexão. 0 que nos coloca a questão: como pensar não-linearmente? Essa superfície complexa, de caminhos e velocidades múltiplos, exige saberes e riscos, sem a garantia de um caminho definitivo. Não responde ao registro da verdade, a não ser que tenhamos em mente seu sentido etimológico: não-esquecimento. Portanto, é verdade nos escritos aquilo que está registrado, pois não-esquecido. Se o vernáculo determina mentira como oposto à verdade, isso já não funciona para a indicação etimológica na língua grega. Verdade é alêtheia. Sem a partícula negativa, lêthê é esquecimento. Mentira é pseydos. Quando uso o termo, dou-lhe conotação peculiar, de modo que a língua portuguesa não nos ajuda muito para investigarmos seu alcance. Também não podemos trazer à discussão o oposto do esquecimento, lembrança. Esses conceitos funcionam muito bem na cosmovisão platônica, na qual cabe à filosofia fazer uma reminiscência das idéias perfeitas. Com isso, pretendo esvaziar o sentido dado à verdade nesse tipo de pesquisa, pois seu conceito não auxilia muito na minha elaboração.

A metáfora despertada pela escuta conciliase com a de labirinto: o ouvido, em sua anatomia, aproxima-se da forma labiríntica. 0 elemento de composição ot(o), no dicionário Aurélio, tem, entre outros, o sentido de "labirinto membranoso" parte da fisiologia do ouvido interno. Escutar, portanto, é percorrer o labirinto das significações das forças presentes na produção humana, nos escritos, na autobiografia.

\section{Escuta das vivências presentes nos escritos}

Quando tomo o pensamento de Nietzsche como operador de conceitos, procuro elementos que contribuam para a compreensão de um determinado tipo de fenômeno que julgo complexo o suficiente para evitar dar-lhe um tipo de tratamento que perderia toda a potencialidade de produção e criação, própria dos escritos. Otobiografia permite aproximações para além dos tratamentos estatísticos, das análises de discurso, das tabulações de recorrências ou outros procedimentos que o sejam. Não se procuram as recorrências, pois só com elas é que podemos dar tratamento estatístico. Abro-me às diferenças, ao intempestivo, à assinatura. Isso não significa desprezar repetições, mas devem ser tratadas como sugere Deleuze (1988): “a repetição só é uma conduta necessária e fundada apenas em relação ao que não pode ser substituído. Como conduta e como ponto de vista, a repetição concerne a 
uma singularidade não trocável, insubstituível" (p. 22). Por isso, não cabe outro tratamento à poesia a não ser repeti-la exatamente como foi escrita, pois é insubstituível. Assim, procuro fidelizar-me ao conhecimento produzido nos escritos, repetindo a diferença que possui cada produção, respeitando e publicando suas assinaturas. Também, buscam-se os vestígios das forças atuantes na produção textual, que são entrevistas ou explicitadas nos textos. Não há pretensão de tratar escritos como dados, por pressupor uma relação que não está estabelecida: a do pesquisador neutro e distante de seu objeto. Coloca-se como ouvinte desses conhecimentos produzidos por autores. Instrumentalizam-se, portanto, os ouvidos para ouvir as vivências presentes nos escritos para recolher assinaturas e estilos. Quando um texto é produzido, as vivências são anotadas, fertilizadas, alimentadas ${ }^{7}$.

E o que escutar? Ora, nada mais apropriado do que as forças presentes nos escritos, reveladas e aprendidas pelas vivências. Portanto, o pesquisador se coloca como ouvinte das vivências na produção escrita. Estas não estão no divã. Não as coloco sobre a bancada farmacêutica da análise clínica. Não são meus objetos. Fazer otobiografia é saber escutar as vivências. São elas que nos mostram os valores e os saberes efetivados, as afeições dos seus autores.

É necessário mais do que ouvidos para escutar as vivências: ninguém tem acesso a elas se não houver vivências em comum, pois ninguém escuta mais do que já sabe. Não sendo acessado por vivências, não se tem ouvido, repito mais outra vez. Também não basta acordo acerca do uso das palavras:

Não basta utilizar as mesmas palavras para compreendermos uns aos outros; é preciso utilizar as mesmas palavras para a mesma espécie de vivências interiores, é preciso, enfim, ter a experiência em comum com o outro. (Nietzsche, 1996, p.182)

Um escrito nada mais é do que a mobilização de suas vivências, significadas pelos textos lidos e pelos discursos ouvidos. São im- pulsos que "tomam a palavra, dão as ordens", diz o filósofo alemão,

[...] isso determina por fim a sua tábua de bens. As valorações de uma pessoa denunciam algo da estrutura de sua alma, e aquilo em que ela vê suas condições de vida, sua autêntica necessidade. (Nietzsche, 1996, p.183)

\section{Considerações finais}

Estabeleci a otobiografia como um tipo de investigação de escritos. Seu método de questionamento é dado pela fórmula Quem? Torna-se o otobiográfico um sintomatologista, um tipologista, um genealogista visto que se põe à procura das origens das forças ativas ou relativas na labiríntica produção escrita.

Como alguém se torna o que é? Essa trilha de investigação, Nietzsche a estabelece a partir de si mesmo. Apresenta ao público Ecce $H_{o m o}{ }^{2}$. Ao prever que deve dirigir-se, em breve, à humanidade com séria exigência, julga indispensável dizer quem é, ou melhor, como se tornou o que é. Como se tornou tão sábio? Quando fez de sua filosofia sua vontade de vida, ou seja, quando se tornou livre do ressentimento, tornou-se guerreiro para superar-se, para ir além-do-homem, experimentou na vida das alturas longe da pequenez do pensamento que não põe o corpo em movimento. Como se tornou tão esperto? Quando refletiu sobre problemas realmente sérios: alimentação, lugar, clima, distração, toda casuística do egoísmo. Aplicou para si a fórmula para a grandeza do homem: nada querer diferente do que se vive. Como escreveu livros tão bons? Ele escreveu o que viveu. Teve as menores orelhas que existiram. Em sua arte de estilo, comunicou estados interiores, um pathos mais rico de si mesmo, mais novo do que nunca, cheio de vontade e energia, relutância e apatia, vontade de potên-

7. Nietzsche desenvolve essa idéia no seu livro Aurora, § 119.

8. 0 livro é estruturado em quatro capítulos: 1) Por que sou tão sábio; 2) Por que sou tão esperto; 3) Por que escrevo livros tão bons; 4) Por que sou um destino. 
cia - nome que dá à vida. Como se tornou um destino? Quando se viu dinamite, transvalorando todos os valores: destruiu as verdades, chamou de bem o que é mal, que de mau o que é bom. Foi além de bem e mal. Ele criou valores, tornou-se moralista, pois sempre disse sim!

Ir além dos modelos investigativos estabelecidos, a partir de Nietzsche, se fará pelo aprendizado da ausculta dos sintomas, dos tipos, das origens das forças e das afeições das vivências. Elas encharcam os escritos.

0 termo que estou usando para esse método é otobiografia. Reconheço ser um termo ambivalente: ao mesmo tempo em que se propõe crítico, mostra a passividade do ouvir, como foi contado por Nietzsche no texto $O$ futuro de nossas instituições de ensino. 0 método otobiográfico se propõe a ouvir a vivência implicada nos estilos do texto. Uma pesquisa que se pretenda otobiográfica não coleta dados; recolhe e espalha: emprega, mesmo sob a pena de contrafação, conceitos já fabricados, experimentando-os em outros espaços. Nessa subversão, almeja deparar com o novo, o original: aquilo que é gerado em novo ambiente: uma espécie de abiogênese. Nessa tensão entre a tradição e a novidade, se busca fundar a intenção de ouvir as vivências.

Alguns pontos precisam ser estabelecidos. Para ouvir as vivências deve-se assumir o emissor como produtor de conhecimento qualificado. Portanto, as produções escritas não podem ser tomadas como objeto, pois na coincidência entre obra e autor estaríamos, no limite, tratan- do-os como objeto de pesquisa. Teríamos um problema ético ao tratar sujeitos como objetos: haveria prática de violência. Em segundo lugar, esse outro modo de ouvir as vivências é estabelecedor de diálogo, pois interpola a crítica à produção escrita, à medida que entende crítica como momento de diálogo que procura mostrar as possibilidades e os limites de determinado argumento, de determinada produção. Diálogo é o que se faz com a produção escrita.

Para concluir, transcrevo um discurso de Zaratustra acerca "Do ler e escrever":

De tudo o que se escreve, aprecio somente o que alguém escreve com seu próprio sangue. Escreve com sangue; e aprenderás que o sangue é espírito. Não é fácil compreender o sangue alheio; odeio todos os que lêem por desfastio. [...] Aquele que escreve em sangue e máximas não quer ser lido, mas aprendido de cor. [...] Máximas, cumpre que sejam cumes; e aqueles aos quais são ditas devem ser altos e fortes. 0 ar rarefeito e puro, a vizinhança do perigo e o espírito imbuído de uma alegre malvadez: coisas que combinam bem uma com a outra. [...] É verdade: amamos a vida, porque estamos acostumados não à vida, mas a amar. [...] Eu acreditaria somente num deus que soubesse dançar. [...] Agora, estou leve; agora vôo; agora, vejo-me debaixo de mim mesmo; agora, um deus dança dentro de mim. Assim falou Zaratustra. (Nietzsche, 2000, p. 66-67) 


\section{Referências bibliográficas}

DELEUZE, G. Diferença e repetição. Tradução de Luiz Orlandi e Roberto Machado. Rio de Janeiro: Graal, 1988.

Em que se pode reconhecer o estruturalismo? Tradução de Hilton F. Japiassú. In: CHÂTELET, F. História da filosofia: idéias, doutrinas. v. 8. Rio de Janeiro: Zahar, 1974.

Mistério de Ariadne ["Mystère d'Ariane" in Magazine littéraire 298 (April 1992), p. 20-24]. Tradução de Edmundo Cordeiro. In: DELEUZE, G. 0 Mistério de Ariana: cinco textos e uma entrevista. Lisboa: Vaga Limitada, 1996.

Nietzsche e a filosofia. Tradução de António M. Magalhães. Porto: Rés, s/d.

DERRIDA, J. Otobiographies: I'enseignement de Nietzsche et la politique dun nom propre. Paris: Galilée, 1984.

. Margens da filosofia. Tradução de Joaquim Torres Costa e António M. Magalhães. Campinas: Papirus, 1991.

DESCARTES, R. Objections and replies. Tradução de John Cottingham. Citado da edição eletrônica "Past Masters: The Continental Rationalists". Essa edição de Objections and Replies foi elaborada tendo como base The Philosophical Writings of Descartes, v. II. Cambridge University Press, 1984.

MARTON, S. Extravagâncias: ensaios sobre a filosofia de Nietzsche. São Paulo: Discurso Editorial; Editora UNIJUÍ, 2000.

Nietzsche: das forças cósmicas aos valores humanos. São Paulo: Brasiliense, 1990.

Nietzsche. A transvaloração dos valores. São Paulo: Moderna, 1993.

NIETZSCHE, F. Além do bem e do mal. Prelúdio a uma filosofia do futuro. Tradução de Paulo César de Souza. São Paulo: Companhia das Letras, 1996.

Assim falou Zaratustra. Tradução de Mário da Silva. Rio de Janeiro: Civilzação Brasileira, 2000.

Crepúsculo do ídolos. Tradução de Paulo César de Souza. São Paulo: Companhia das Letras, 2006.

Ditirambos de Dionísos. Tradução de Manuela Sousa Marques. Lisboa: Guimarães Editores, 2000a.

Ecce Homo. Tradução de Paulo César de Souza. São Paulo: Companhia das Letras, 1995.

Fragments posthumes. Automne 1884 - Automne 1885. Traduits par Michel Haar et Marc B. De Launay. Paris: Gallimard, 1982.

La naissance de la tragédie. Fragments posthumes. Automne 1869 - pritemps 1872. Traduits par Michel Haar, Philippe Lacoue-Labarthe et Jean-Luc Nancy. Paris: Gallimard, 1977.

Sobre o futuro dos nossos estabelecimentos de ensino. Escritos sobre Educação. Organização, tradução, apresentação e notas de Noéli Correia de Melo Sobrinho. Rio de Janeiro: Ed. PUC-Rio; São Paulo: Loyola, 2003.

Recebido em 23.10.06

Aprovado em 21.05.07

Silas Borges Monteiro, graduado em filosofia e doutor em Educação pela USP, é professor adjunto do Departamento de Teoria e Fundamentos da Educação da Universidade Federal de Mato Grosso, atendendo aos cursos de Pedagogia e Filosofia, e também professor do Programa de Pós-Graduação em Educação da UFMT. 